UDC 81'25

doi: 10.22250/2410-7190_2021_7_3_18_25

\author{
Bakitgul E. Borankulova \\ L. N. Gumilyov Eurasian National University \\ Nur-Sultan, Kazakhstan \\ b_bakit@mail.ru \\ Zoya G. Proshina \\ Lomonosov Moscow State University \\ Moscow, Russian Federation \\ proshinazoya@yandex.ru
}

\title{
New vocabulary related to coronavirus: The potential of its use in the Kazakh language and the problem of translation
}

\begin{abstract}
This article aims to collect, group and conduct a linguistic study of coroneologisms - new words and phrases formed during the Covid-19 outbreak, to analyze their translation into Kazakh and determine the potential for their use in the language. The materials for the study were taken from (i) the websites of a national Kazakh newspaper, (ii) an official site of the Ministry of Healthcare of the Republic of Kazakhstan and its instagram, (iii) English-language newspapers, (iv) materials from online Merriam-Webster Dictionary. Continuous sampling was used to select the tokens for the study. Having analyzed new words and expressions related to coronavirus, their usage in English and translation into Kazakh, we can say that some comparatively new words and expressions that describe a specific situation (lockdown, WFH (working from home), social distancing, etc.) belong to particular professional vocabulary and have already been introduced into the dictionaries in many languages. The discourse potential of such phrases as COVID-19, SARS-CoV-2 and coronavirus-related words and word-combinations remains high expanding the range of terms in the field of medicine. The status of the Kazakh versions of the new terms still remains challenging as far as they are not introduced into Kazakh dictionaries and are not approved by the Terminological commission of the country. Despite these facts, they continue their "illegal" functioning in Kazakh newspapers and on the country's Ministry of Healthcare website.
\end{abstract}

Keywords: coronavirus, coroneologism, online dictionaries, usage potential, medical discourse, ways of translation.

(C) Borankulova B. E., Proshina Z. G. 2021

For citation: Borankulova, B. E., Proshina, Z. G. (2021). New vocabulary related to coronavirus: The potential of its use in the Kazakh language and the problem of translation. Teoreticheskaya i prikladnaya lingvistika [Theoretical and Applied Linguistics], 7 (3), 18-25. doi: 10.22250/2410-7190_2021_7_3_18_25.

\section{Introduction}

At the end of 2019, an epidemic similar to pneumonia got an outbreak and began to spread around the world. The World Health Organization has determined that the causative agent of the disease is a new type of coronavirus $2019-\mathrm{nCoV}$ and declared it as a pandemic.

The people of the world began to talk about the name of the epidemic, its danger to the body and even to human life. Many new words related to a new Covid-19 virus have appeared in the English-language media and on the Internet. The terms isolation, selfquarantine, social distance, PPE (personal protective equipment), WFH (work from home), and PCR test (polymerase chain reaction test) were often mentioned, indicating actions that require the population to take precautions in connection with the pandemic. Among the population, there were people who reacted with distrust to the existence of the virus in the 
environment and did not take (perform) precautions or vice versa those who followed preventive measures from being infected with the disease. They were called covidiot and covidient accordingly. In this regard, some English online dictionaries such as MerriamWebster Dictionary and others have updated their vocabulary entries.

The purpose of this article is to collect, group, and conduct a linguistic analysis of new words and phrases formed during the Covid-19 outbreak, analyze their translation into Kazakh, and determine the potential of their use in the language.

It is known that any new phenomenon in the world suggests the formation of a new term to name it. Consequently, the new term increases word-stock of languages. But whether this new word becomes active or passive in use, or else it discontinues to be used in languages at all is a matter of situation. Due to the Covid-19 pandemic, medical terminology saw this fact too. As we have stated above, many new words and expressions connected with the Covid-19 appeared in terminology. In 2020, Merriam-Webster Dictionary added to its entry Covid-19-related new specialized medical words and divided them into some semantic groups. For instance, Covid-19, coronavirus (names of disease), index case, patient zero, etc. (diagnose) [Coronavirus and the new words...]. Moreover, there are some linguistic units due to any new phenomenon which acquire another meaning, id est secondary nominated terms. According to V. M. Leychik, secondary nomination is the use of already available linguistic units in performing new nominative functions [Leychik, 2009. p. 47]. For instance, cordon sanitaire, social distance and lockdown. Though these terms have an etymological history in their emerging and usage in different spheres of science, lexicographers expanded or revised definitions according to medical context due to the pandemic and added them to the entries of the online dictionaries.

Global dimension of the disease and, correspondingly, Covid-related and Covidinspired vocabulary has motivated an increase in investigating the phenomenon. Recent studies have contributed to collecting the emerged units across English and other languages as well as their word building pattern analysis including affixation, abbreviation, compounding, blending etc. (see multiple tokens analyzed by [Al-Salman, Haider, 2021; Mweri, 2021]). According to [Thorne, 2020], there are over 1000 neologisms ranging from non-specialized words to technical terms in English. Some linguists focus more on new medical and technical terms, while others pay greater attention to coroneologisms that come from the laity and embrace European languages whose word-stocks share a common Latinate substratum [RoigMarín, 2020]. Researchers have also attempted to examine slogans as a part of social policy during the pandemic (see e.g. the works of [Dubinina, 2021; Li Xin, Starodubtseva, 2021] based on Chinese). All this activity has sparkled the interests of specialists in applied linguistics for designing corpora and performing corpus analysis of covid-19 language [Cameron, 2020; Covid-19 language hub; Hua Tan et al., 2020; Butler, SimonVandenbergen, 2021; Schweinberger et al., 2021]. They examine terms, collocations, true information manifestation vs fakes about Covid-19 etc.

These studies based on all sorts of discourses (primarily Englishes - American, Australian, British, Malaysian etc.) from government addresses to personal posts clearly show that the lexicon of people, whether they are specialists or ordinary ones, enlarged. The new vocabulary is used by medical specialists, officials, mass media specialists and in the hoi polloi.

One of these sources presented a multilingual project based on 19 languages including European, Asian and African ones [Covid-19 language hub] with no data on the Kazakh language. However, the Kazakh language is no exception to the process of emerging and spread of new words connected with coronavirus, and this fact motivated our study. We aimed to study the ways coroneologisms are used if they are translated, particularly into Kazakh, as well as the ways they are translated into this language. 


\section{This study}

\subsection{Material and methods}

Several sources were used to collect the material for this study. For the Kazakh part, website of national Kazakh newspaper "Жас Алаш" 'Young Alash' [Жас Алаш], official Instagram page and website of the Ministry of Healthcare of the Republic of Kazakhstan [Қазақстан Республикасы...] and Russian-Kazakh Kazakh-Russian dictionary [Sozdic]. For the English part, newspapers [BBC News; The Guardian] were used as well as MeriamWebster dictionary [Coronavirus and the new words...].

Continuous sampling was used to select the tokens for analysis. The search terms for Kazakh included коронавирус, ковид, тәжвирус, etc. The total of 52 Kazakh tokens and 63 English tokens were analyzed in contexts.

\subsection{Results and discussion}

The study of Kazakh coroneologisms and comparison with their English donors enabled to identify the following ways of translation that introduced these lexical units into Kazakh vocabulary in use: transliteration, semi-calque, metaphoric translation and word-forword translation. Below, we will discuss typical examples and the ways of their translation.

The first block of examples comes from "Жас Алаш" newspaper [https:// www.zhasalash.kz]. The following examples illustrate different translation patterns: transliteration of the abbreviation PCR (1-1), equivalent of isolation (1-2), transliteration of the noun quarantine (2-1) that had existed before the pandemic and then acquired a new meaning and the noun lockdown (2-2), metaphoric translation of coronavirus (3).

(1) Індет жұқтырғандарды оқшаулауза ${ }^{(1-2)}$ мүмкіндік бар - 'It is possible to identify and isolate ${ }^{(1-2)}$ infected people by $\boldsymbol{P C R}^{(1-1)}$ testing in due time'.

(2) Қазақсттанда карантин (2-1) жеңілдетілді: Бүгіннен бастап бизнес локдауннан ${ }^{(2-2)}$ mblzadbl - 'Quarantine(2-1) in Kazakhstan has been relaxed: As of today business will come out of a lockdown ${ }^{(2-2) '}$.

(3) Құрыъы ұзын қытайвирус бейбіт жатқ̧ан ауылда жетті - 'Long-armed coronavirus has reached the peaceful village'.

The second block of examples is taken from an official Instagram page and website of the Ministry of Healthcare of the Republic of Kazakhstan where parallel texts (English and Kazakh) about Covid-19 were posted. An original English sentence containing coroneologism and its analogue from the Kazakh text are given below [https://www.instagram.com/ healthcare.gov.kz/]:

(4) Symptoms of novel Coronavirus: fever, cough, shortness of breath - 'Жаца коронавирустың белгілері: дене қызуының көтерілуі, жөтел, тыныс алудың қиындауы'.

In addition to the existing Kazakh equivalents of English standard (and quite old) medical terms like symptoms 'белгілері', fever 'дене қызуының көтерілуі', cough 'жөтел', shortness of breath 'тыныс алудың қиындауы', a "pure"l coroneologism is given - novel Coronavirus 'жаңа коронавирустың' where жаңа is an equivalent to novel and коронавирустьц арpeared as a result of transliteration - коронавирус +тың where тың is the suffix of the possessive case similar to the one in English.

Another example is a title of an instruction.

\footnotetext{
${ }^{1}$ The one that has not existed in the language before the pandemic.
} 
(5) СОVID-19 коронавирустық инфекция мәселелері бойынша халыққ̧а арналван ұсыныстар - 'Coronavirus disease (COVID-19) advice for the public' [https:// www.gov.kz/memleket/entities/dsm/press/news/details/51537?lang=kk].

The expression from the source text COVID-19 коронавирустық инфекция is translated into the target text as 'Coronavirus disease (COVID-19)'. We view example (5) as demonstrating tautology in the Kazakh source text. If in the Kazakh language коронавирустық инфекиия тау be translated into English as coronavirus infection, then it is given as Coronavirus disease and COVID-19 is taken in brackets. Therefore, the very use of the word-combination коронавирустық инфекция in the Kazakh sentence is redundant as the term COVID-19 already means 'coronavirus disease 19, CO-corona,VI-virus, D-disease'.

We will finish examples analysis with an abbreviation [https://www.gov.kz/memleket/ entities/dsm/press/news/details/44604?lang=en]:

(6) Бұл орталық жсаца коронавирусты ПТР-диагностикалау ддістемесін игерген - 'Specialists in this center have mastered the technique for $\boldsymbol{P C R}$-based diagnostics of the new coronavirus'.

In this sentence, one of the coronavirus-related terms is an abbreviation $\Pi T P$ which is a word-for-word translation of English $P C R$ - polymerase chain reaction test, and it stands for полимеразды тізбекті реакиия.

For every Kazakh coroneologism, the way of translation was identified. Table 1 arranges the obtained results.

\section{$\mathrm{T}$ a b 1 e 1. Translations of English coronavirus-related words and word-combinations into Kazakh}

\begin{tabular}{|c|c|c|}
\hline English & Kazakh variants & Ways of Translation \\
\hline \multirow{2}{*}{ coronavirus, $\mathrm{n}$} & 1. коронавирус, $\mathrm{n}$ & 1. transliteration \\
& 2. тәжвирус, $\mathrm{n}$ & 2. semi-calque \\
& 3. тәжтажал, $\mathrm{n}$ & 3. metaphoric translations \\
& 4. қытайвирус, $\mathrm{n}$ & . metaphoric translation \\
& 5. қазақ тұмауы, $\mathrm{n}$. in possessive case & word-for-word translation \\
\hline novel coronavirus & жаңа коронавирус & transliteration \\
\hline Covid-19, $\mathrm{n}$ & Ковид-19 & word-for-word translation \\
\hline
\end{tabular}

During the study, we have encountered many coronavirus-related words and wordcombinations and associations in English and Kazakh languages in the mass media (printed and audiovisual). The study showed that most of the Kazakh versions can be considered as the translations of those English ones. The lists given below demonstrate that. The list of coroneologisms in Kazakh (List 1) comprises 103 lexical units. It was triggered by 73 corresponding ones found in English mass media (List 2). As we can see, the Kazakh list outnumbers the English one. This discrepancy is explained by a different number of synonymous coroneologisms in the two languages. For instance, the word coronavirus has 5 and the word-combination social distancing 4 different synonymous translations. However, the majority of them has not been introduced into Kazakh yet.

List 1. Coronavirus related words and word-combinations in Kazakh

Корона / Коронавирус; тәжвирус; тәжтажал / Жаңа коронавирус / 2019-nCоV / COVID-19; Ковид-19; КВИ; Індет; Кесел; Қазақ тұмауы; Қытайвирус / Тұмау тәрізді / Өршу / Вирус / Эпидемиялық / Пандемия / Карантин / Елдегі төтенше жавдай / Өзін-өзі 
оқұшаулау / Оқцаулау; изолящия / Санитарльққ бекініс; блок-пост / Коронавирустьци бар екендігіне сенбейтін / Коронавирустың бар екендігіне сенетін / ПТР тест (полимеразды тізбекті реакиия) / Клиникалық зерттеу / Алгашқ̧ы жұқтырушы / Науқ̧ас саны; жұқтыру көрсеткіші / Коронавирустық инфекция белгісі бар / Коронавирустық инфекция белгісі жоқ / Жедел респираторль стресс синдромы (ЖРСС) / Расталван оң жавдай / Болжалдь оң жавдай / Контактіде болмаван; байланыста болмаван / Иммунитет / Ұжымдық иммунитет / Инкубацияльққ кезең / Таралу / Қовамzа таралу, ортава таралу / Жұқ̆аль / Контагиозды; жұқ̧паль / Аурушаңъдық / Өлім-жітім / Тез; жылдам таравыш / Берілу; жұву; таралу / Науқаспен контактіде ; байланыста болванды құадавалау / Үйде болу; үйде отыру / Локдаун / Бетперде; маска; тұмша / Санитайзер / Маңдайва арналван термометр; қъызу өлшегіш / Респиратор / Вентилятор; ауа желдеткіш / Әлеуметтік құашықтық; әлеуметтік арақашықтыққ; длеуметтік алшақтық; длеуметтік аралық / Адамнан адамва жұватын; таралатын; берілетін / Жеке қэорваныш заттары / Үйде жұмыс жасау / Тамшы арқыьль берілу; таралу / Науқ̧ас көрсеткішінің көбеюі / Коронавирус толқыны / Аурудың алдын алу жсне құадавалау ортальқтары / SARS-CoV-2 / MERS-CoV / Covax вакиинасы/ Вакиина; екпе / Кавасаки синдромы / Кавасаки ауруы / Инфодемия / Провизорльққ ортальқ / Жасыл аймақ / Сары аймақ / Қызылл аймақ / Өкпені жасанды желдету аппарать / Оттегі кониентраторы / Маска режимі; бетперде кию тәртібі; бетперде кию ережесі / Клиникальқ белгілері жоқ тасыммалдаушы / Клиникалық белгілері бар тасымалдаушы / Ковид такси / Корона-давдарыс.

List 2. Coronavirus related words and word-combinations in English

Corona / Coronavirus / Novel Coronavirus / 2019-nCoV / COVID-19 / Flu-like / Outbreak / Virus / Epidemic / Pandemic / Quarantine / National emergency / Self-quarantine / Isolation / Cordon sanitaire / Covidiot / Covidient / PCR test (Polymerase chain reaction test) / Clinical trial / Index case / Index patient / Patient zero / Symptomatic / Asymptomatic / Acute respiratory stress syndrome (ARDS) / Confirmed positive case / Presumptive positive case / Contactless / Immunity / Herd immunity / Incubation period / Spread / Community Spread / Communicable / Contagious / Morbidity / Mortality / Super-spreader / Transmission / Contact tracing / Stay-at-Home / Lockdown / Facemask / Sanitizer / Forehead thermometer / Respirator / Ventilator / Social distancing / Human-to-human / PPE (personal protective equipment) / WFH (working from home) / Droplet transmission / Flattening the curve / Tsunamis of COVID-19 cases / CDC (Centres for Disease Control and Prevention) / SARS-CoV-2 / MERS-CoV / Covax / Vaccine / Kawasaki syndrome / Kawasaki disease / Infodemy / Provision center / Green zone / Yellow zone / Red zone / Artificial ventilation devices / Oxygen concentrator / Mask regime / Covid Taxi / The corona crisis.

Out of the Kazakh list of 103 coroneologisms and corona-related associations, 12 of them emerged as a result of transliteration, 10 appeared as semi-calques, 3 due to metaphoric translation, 8 are transcriptions, 14 are word-for-word translations, 4 are descriptive translations, and 70 are Kazakh equivalents. Very few if any coroneologisms introduced into Kazakh from English since the outbreak of the pandemic have entered the governmentsupported Russian-Kazakh / Kazakh-Russian online dictionary.

\section{Conclusion}

The study of the 103 Kazakh and 73 English coroneologisms and corona-related associations enables to draw several conclusions. First of all, almost $68 \%$ of Kazakh units are the equivalents that have existed in the language, around $12 \%$ resulted from transliteration, $10 \%$ emerged as semi-calques, a little over $20 \%$ were various translations $(3 \%$ metaphoric, around $4 \%$ descriptive and $13,6 \%$ word-for-word), and around $8 \%$ were transcriptions. 
As for the English part, the word Coronavirus and its variants as COVID-19, SARS, $\mathrm{CoV}-2, \mathrm{MERS}-\mathrm{CoV}, \mathrm{nCOV}$ are sure to be new medical terms. They have already been introduced into the dictionaries of almost all the languages. As far as the derivatives of the Covid such as slangs covidient, covidiot are concerned, they might disappear from use. Special medical terms as community spread, herd immunity, etc. are likely to stay in medical discourse only as soon as the pandemic is over. It should be admitted that the discursive potential of COVID-19, SARS-CoV-2 and certain coronavirus-related words and wordcombinations might be quite high as they have already expanded the range of terms in the field of medicine.

As for the Kazakh translations of the new terms, the issue still remains challenging as almost none of them is included in Kazakh dictionaries except for those that have already existed in the language. However, their new meanings have been neglected so far. Meanwhile, the existing translation variants of a pure coroneologism Covid-19 as тәжтажсал (metaphorical translation of a combination of 2 stems: corona + death), қылтайвирус (metaphorical translation of a combination of 2 stems: China+virus), қазақ тұмаy (metaphorical translation of a combination of 2 stems: Kazakh+flu), індет (general term used to denote epidemic) and коронавирус (transliteration) are not approved by the Terminological commission of the country. Therefore, the official status of coroneologisms in Kazakh remains unclear.

Despite this neglect, coroneologisms - single words and word-combinations from the Covid-19 pandemic - have developed the word-stock in Kazakh and being officially misnomers, they continue functioning on official websites. These words definitely have high methodological potential, e.g. in English as L2 studying and teaching as suggested by [Shamina et al., 2020] who successfully exploited different types of discourse including humorous songs that produce various highly emotional reactions. This potential can be realized in any language teaching as L1 or L2, including Kazakh. The Covid-19 pandemic being a current issue of the contemporary world could trigger hot discussions boosting the interest in the language as a part of any curriculum.

\section{References}

Al-Salman, S., Haider, A. S. COVID-19 trending neologisms and word formation processes in English (2021). Russian Journal of Linguistics, 25 (1), 24-42. doi : 10.22363/2687-0088-2021-25-1-24-42.

Butler, C. S., Simon-Vandenbergen, A. M. (2021). Social and Physical Distance/Distancing: A CorpusBased Analysis of Recent Changes in Usage. Corpus Pragmatics. doi : 10.1007/s41701-02100107-2.

Cameron, J. (2020). Corpus analysis of the language of Covid-19. ODE. Oxford English Dictionary. The definitive record of the English language. Retrieved April 15, 2020 from <https:// public.oed.com/blog/corpus-analysis-of-the-language-of-covid-19/>.

Covid-19 language hub. OxfordLanguages. Retrieved April 3, 2021 from <https://languages.oup.com/ covid-19-language-resources/>.

Dubinina, M. N. (2021). Semanticheskiy analiz lozungov epokhi pandemii v Kitae [Semantic analysis of slogans during the pandemic in China]. Filologicheskie nauki. Voprosy teorii $i$ praktiki [Philology. Theory \& Practice], 14 (2), 475-483. (In Rus.).

Hua Tan, K., Woods, P., Azman, H., Abdullah, H. I., Hashim, R. S., Rahim, H. A, Idrus, M. M., Said, N. E. M, Lew, R., Kosem, I. (2020). Covid-19 insights and linguistic methods. The Southeast Asian Journal of English Language Studies, 26 (2), 1-23. doi : 10.17576/3L-2020-2602-01.

Leychik, V. M. (2009). Terminovedenie: predmet, metody, structura [Terminology studies: Focus, methodology, structure]. 4th edition. Moscow : LIBROKOM Press. (In Rus.).

Li Xin, Starodubtseva, N. V. (2021). Lozungi na rabotakh masterov nematerial'nogo kul'turnogo naslediya Kitaya kak sredstvo bor'by s epidemiey koronavirusnoy infektsii (COVID-19) [Slogans on the works of masters of China's intangible cultural heritage as a means of combating the 
epidemic of coronavirus infection (COVID-19)]. Teoreticheskaya i prikladnaya linguistika [Theoretical and Applied Linguistics], 7 (3), 116-130.

Mweri, J. (2021). Corona Virus Disease (COVID-19) Effects on Language Use: An Analysis of Neologisms. Linguistics and Literature Studies, 9 (1), 36-47. doi : 10.13189/1ls.2021.090105.

Roig-Marín, A. (2020). English-based coroneologisms: A short survey of our Covid-19-related vocabulary. English Today, 1-3. doi :10.1017/S0266078420000255.

Schweinberger, M., Haugh, M., Hames, S. (2021). Analysing discourse around COVID-19 in the Australian Twittersphere: A real-time corpus-based analysis. Big Data and Society, 8(1). doi : 10.1177/20539517211021437.

Shamina, E. A., Besedina, E. I., Kuzmich, I. V. (2020). Sovremennyy angloyazychnyy diskurs v usloviyakh pandemii: metodicheskiy potentsial [Contemporary English language discourse during the pandemic: Methodological potential]. Teoreticheskaya i prikladnaya linguistika [Theoretical and Applied Linguistics], 6 (4), 170-181. (In Rus.).

Thorne, T. 2020. \#CORONASPEAK - the language of Covid-19 goes viral. Retrieved April 30, 2020 from $<$ language-and-innovation.com/2020/04/15/coronaspeak-part-2-the-language-of-covid-19-goes-viral/>.

\title{
Sources for the material
}

BBC News. Retrieved April 5, 2021 from <https://www.bbc.com/news/av/world-asia-india-51962813>.

Coronavirus and the new words we added to the dictionary in March 2020. Meriam-Webster. Retrieved from $<$ https://www.merriam-webster.com/words-at-play/new-dictionary-words-coronavirus-covid-19>.

The Guardian. Retrieved April 5, 2021 from <https://www.theguardian.com/world/2020/aug/26/covid19-world-map-countries-coronavirus-cases-death>.

Жас Алаш [Young Alash]. Retrieved from <https://www.zhasalash.kz>.

Instagram Қазақстан Республикасы Денсаулық сақтау министрлігі [Instagram of the Ministry of Healthcare of the Republic of Kazakhstan]. Retrieved from <https://www.instagram.com/ healthcare.gov.kz/>.

Қазақстан Республикасы Денсаулық сақтау министрлігі [Ministry of Healthcare of the Republic of Kazakhstan]. Retrieved from <https://www.gov.kz/memleket/entities/dsm/press/news/details/ 51537?lang $=\mathrm{kk}>$.

Sozdik: Russko-kazakhskiy/kazakhsko-russkiy slovar [Russian-Kazakh / Kazakh-Russian dictionary]. Retrieved April 5, 2021 from <https://sozdik.kz/ru/>.

УДК 81'25 doi: 10.22250/2410-7190_2021_7_3_18_25

Боранкулова Бакитгуль Ержигитовна

Евразийский национальный университет им. Л. Н. Гумилева

г. Нур-Султан, Казахстан

b_bakit@mail.ru

Прошина Зоя Григорьевна

Московский государственный университет им. М. В. Ломоносова

г. Москва, Российская Федерация

proshinazoya@yandex.ru

\section{Новая лексика, относящаяся к коронавирусу: её потенциал в казахском языке и проблема перевода}

\begin{abstract}
Аннотация
В данной статье поставлена цель собрать, сгруппировать и провести языковой анализ ковидных неологизмов - новых слов и фраз, образовавшихся во время вспышки Covid-19, проанализировать их перевод на казахский язык и определить потенциал их использования в языке. Материалы для анализа были взя-
\end{abstract}


ты из нескольких источников: 1) сайта республиканской газеты, 2) официального сайта Министерства здравоохранения Республики Казахстан и публикаций в инстаграме Министерства, 3) англоязычных газет, 4) онлайн-словаря Merriam-Webster Dictionary. Целевая лексика отбиралась методом сплошной выборки. Проанализировав новые слова и выражения, связанные с коронавирусом, их использование в английском языке и перевод на казахский язык, мы можем сказать, что некоторые сравнительно новые слова и выражения, описывающие конкретную ситуацию (lockdown, WFH (working from home), social distancing, etc.), используются исключительно в составе профессиональной лексики и уже введены в онлайн словари многих языков. Дискурсивный потенциал таких фраз, как COVID-19, SARS-CoV-2 и связанных с коронавирусом слов и словосочетаний остаётся высоким, поскольку они расширили спектр терминов в области медицины. Вопрос о статусе казахских вариантов перевода новых терминов до сих пор остаётся открытым, поскольку они не представлены в официальных казахских словарях и не одобрены терминологической комиссией страны. Тем не менее, они продолжают своё «некодифицированное» существование на официальных сайтах газет и Министерства здравоохранения страны.

Ключевые слова: коронавирус, ковидный неологизм, онлайн-словари, потенциал использования, медицинский дискурс, способы перевода.

(C) Боранкулова Б. Е., Прошина 3. Г. 2021

Для цитирования: Borankulova B. E., Proshina Z. G. New vocabulary related to coronavirus: The potential of its use in the Kazakh language and the problem of translation // Теоретическая и прикладная лингвистика. 2021. Вып. 7, № 3. С. 18-25. doi: 10.22250/2410-7190_2021_7_3_18_25. 